\title{
The Influence of Women Dental Hygienists' Work-Family Balance on Happiness Level in Dental Clinics
}

\author{
Ae-Jung Im, Yun-woo Kim, Su-jung Kim, Seung-yeon Kim, Eo-jin Kim, So-dam Moon, \\ Su-min Shin, Hae-in Jeong, Hee-Ae Jeong, and Hee-Jung Lim $^{\dagger}$ \\ Department of Dental Hygiene, College of Health Science, Eulji University, Seongnam 13135, Korea
}

\begin{abstract}
Background: To identify work-family balance and level of happiness among married women dental hygienists in Seoul and Gyeonggi Province. The goal of this study is to use the outcome as basic data to determine the compatibility of dental hygienists with work and family, systems, and improvement of happiness levels.

Methods: From July 3 to August 10, 2020, 250 dental hygienists in Seoul and Gyeonggi Province were targeted. The questionnaire comprised 65 questions, including general characteristics (perception of work-family balance, perception of work-family balance system, job satisfaction, parenting type, happiness level) whether or not they were implemented. The results were obtained through a self-control questionnaire.

Results: The perception of work-family balance was significantly different in job rank and average income, while that of the workfamily balance system had significant differences in workplace type, total work experience, current job work experience, childcare system status, and parental leave period. Happiness level and job satisfaction were significantly different in job rank, average income, and childcare system status. Additionally, the perception of work-family balance and that of the work-family balance system showed a positive correlation with job satisfaction and happiness level. Finally, the perception of married women dental hygienists toward work-family compatibility was determined, where the higher the satisfaction with the job, the higher the level of happiness.

Conclusion: To improve the work-family balance and job satisfaction of dental hygienists and their levels of happiness, changes in social perception and improvement of the working environment such as proper staffing, flexible work systems, and incentive systems should be considered.
\end{abstract}

Key Words: Dental hygienists, Happiness, Work-life balance

\section{Introduction}

Work-family balance, which is widely referred to as "work-life balance," entails the state created by harmony between individual work and life ${ }^{1)}$. Notwithstanding the gender neutrality of the concept of work-family balance ${ }^{2)}$, it is mainly used to refer to married women with children, and thus, the effectiveness of the work-family reconciliation policy is insufficient ${ }^{2}$. According to the work-family balance indicators of the Korea National Statistical Office in $2018^{3)}$, the number of husbands in favor of their wives' employment (46.6\%) was more than double that of those who opposed it $(19.0 \%)$. However, upon considering the housework ratio of the couple, men accounted for 50 to $60 \%$, while women $99 \%{ }^{4)}$, which showed that women were simultaneously expected to work and do the housework at the same time. In the modern society, with the increase in women's economic activities, the nuclear family has progressed, and the perception that gender roles are divided into men at work and women at home has begun to change ${ }^{5)}$. Thus, the recent economic activity participation rate of women was $50.2 \%$ in $2016,50.8 \%$ in 
2017, and $50.9 \%$ in 2018, which is a very small difference but continues to increase ${ }^{6}$. This phenomenon reflects the modern society in which women's participation in economic activities has increased $^{6}$, which indicates that the proportion of dual-income families is gradually increasing.

Dental hygienists have been defined as "professionals who provide a part of oral health promotion to local residents and people with oral disease, and to lead a life with the goal of improving individual qualities and capabilities"7). The dental hygiene profession consists of a higher number of women than men ${ }^{8}$. As the need for workfamily balance among women has recently increased ${ }^{8)}$, for dental hygienists who combine work and family, a harmonious balance of the same is important. This balance allows one to control and condition one's own life and to be satisfied with it $^{9)}$. A work-family balance can help to improve the quality of dental personnel management and dental care services at the workplace level ${ }^{10)}$. At a national level, establishing a work-family balance plays an important role in becoming a competitive country"

Previous studies on the reconciliation of married women's work and family investigated the turnover intention of married women police officers ${ }^{11)}$ and job satisfaction of social workers ${ }^{12)}$, and studies on work-family reconciliation and happiness level were reported ${ }^{5}$. A study on the workfamily balance of married women dental hygienists reported factors affecting occupational commitment ${ }^{13)}$ and careerinterrupted intention ${ }^{14}$. However, studies on work-family balance and happiness levels targeting dental hygienists were insufficient.

Therefore, this study seeks to identify married women dental hygienists' work-family balance and happiness levels in Seoul and Gyeonggi. Through this, the outcome is intended to be used as basic data for the improvement of work-family balance and system, as well as the happiness level of women dental hygienists.

\section{Materials and Methods}

\section{Subjects}

This study was targeted at married women dental hygienists working at a dental hospital/clinic in Seoul and Gyeonggi-do from July 3 to August 10, 2020. After fully explaining the purpose of the study and obtaining consent, face-to-face interactions were done via the Naver platform. A self-reported questionnaire was administered to the participants. A total of 188 copies were analyzed as final samples, excluding questionnaires with insincere responses among 250 copies of the survey subjects.

\section{Materials}

This study was conducted by modifying and supplementing the questionnaires used in a study on the work-family balance and happiness level of dual-income families ${ }^{5}$ and a study on the effect of job characteristics and job satisfaction for endoscopy nurses ${ }^{15}$.

The questionnaire consisted of 19 questions on the perception of work-family balance, 4 questions on the perception of work-family balance system, 12 items on workplace form, 8 questions on general characteristics, 4 questions on parenting type, and 18 questions on happiness level, which was a total of 65 questions.

\section{1) Work-family balance}

Work-family balance is a concept that explains roles and conflicts for an individual to fulfill their responsibilities at work and in the family. This means that time, emotion, and actions are simultaneously balanced ${ }^{5,16)}$.

\section{2) Perception of work-family system}

The perception of the work-family system refers to the degree of awareness of the leave before and after childbirth, spouse's leave before and after childbirth, parental leave, and the family care leave system ${ }^{2,11}$.

\section{3) Job satisfaction}

This refers to the degree of emotional and positive satisfaction that organizational members feel when performing their duties ${ }^{5,12,15)}$.

\section{4) Happiness level}

This refers to a unit that provides a comprehensive measure of happiness in daily life that consists of psychological relaxation, family and marriage, personal relationships, daily life, economic stability, work, and health ${ }^{5)}$. 
For the perception of work-family balance, "not at all" was 1 point and "very much" was 5 points. Reverse coding was performed to increase the explanatory power of the perception of work-family balance. The lower the score, the higher the level of perception of work-family balance. Cronbach's $\alpha$ was 0.932 . For the perception of workfamily balance system, job satisfaction, and happiness level, 1 point was given for "not at all" and 5 points was given for "very much". Consequently, it was interpreted that the higher the score, the higher the degree. The Cronbach's $\alpha$ values were $0.883,0.876$, and 0.879 , respectively.

\section{Analysis}

The collected data were analyzed using the Statistical Package for the Social Sciences Version 25 (SPSS) program (IBM Corp., Armonk, NY, USA). To investigate the perception of work family balance, perception of work family balance system, job satisfaction, and happiness level according to general characteristics, workplace form, and parenting type, a t-test and one-way ANOVA were used. Verification was conducted using Scheffe's test.

To investigate the correlation between the perception of work-family balance, perception of work-family balance system, job satisfaction, and happiness level, Pearson correlation analysis was performed. Multiple regression analysis was performed to examine the effects of parenting type, perception of work family balance, perception of work family balance system, and job satisfaction on happiness level.

\section{Result}

1. Difference between work-family balance and work - family balance system perception, job satisfaction, and happiness level according to general characteristics

The results of examining the differences between workfamily balance and work-family balance system perception, job satisfaction, and happiness level according to the general characteristics of the study subjects are reported in Table 1.

Among the sub-domains of general characteristics, the group with two or more children showed the highest awareness of the work-family balance system, where the group without children showed the lowest $(p<0.01)$. There was no significant difference between the perception of work-family balance, job satisfaction, and happiness level.

Table 1. Difference between Work-Family Balance and Work-Family Balance System Perception, Job Satisfaction, and Happiness Level according to General Characteristics

\begin{tabular}{|c|c|c|c|c|c|c|c|c|c|}
\hline \multirow{2}{*}{ Variable } & \multirow{2}{*}{$\mathrm{n}$} & \multicolumn{2}{|c|}{$\begin{array}{c}\text { Perception of } \\
\text { work-family balance }\end{array}$} & \multicolumn{2}{|c|}{$\begin{array}{c}\text { Perception of } \\
\text { work-family balance system }\end{array}$} & \multicolumn{2}{|c|}{ Job satisfaction } & \multicolumn{2}{|c|}{ Happiness level } \\
\hline & & Mean \pm SD & $\mathrm{t} / \mathrm{F}$ & Mean \pm SD & $\mathrm{t} / \mathrm{F}$ & Mean \pm SD & $\mathrm{t} / \mathrm{F}$ & Mean \pm SD & $\mathrm{t} / \mathrm{F}$ \\
\hline \multicolumn{10}{|l|}{ Age (y) } \\
\hline $20 \sim 29$ & 36 & $2.97 \pm 0.63$ & 1.390 & $2.76 \pm 0.78$ & 1.928 & $3.24 \pm 0.61$ & 0.271 & $3.11 \pm 0.47$ & 1.957 \\
\hline $30 \sim 39$ & 89 & $3.09 \pm 0.69$ & & $3.08 \pm 0.85$ & & $3.31 \pm 0.48$ & & $3.20 \pm 0.45$ & \\
\hline$\geq 40$ & 63 & $2.65 \pm 0.82$ & & $2.92 \pm 0.93$ & & $3.26 \pm 0.56$ & & $3.20 \pm 0.49$ & \\
\hline \multicolumn{10}{|l|}{ Education } \\
\hline College & 135 & $3.02 \pm 0.70$ & -0.099 & $2.90 \pm 0.90$ & 1.345 & $3.27 \pm 0.55$ & -0.471 & $3.19 \pm 0.44$ & 0.631 \\
\hline$\geq$ University & 53 & $3.03 \pm 0.67$ & & $3.15 \pm 0.78$ & & $3.31 \pm 0.49$ & & $3.31 \pm 0.48$ & \\
\hline \multicolumn{10}{|c|}{ Number of children } \\
\hline None & 50 & $3.15 \pm 0.73$ & 1.732 & $2.62 \pm 0.72$ & $5.874 * *$ & $3.20 \pm 0.59$ & 0.801 & $3.13 \pm 0.51$ & 1.497 \\
\hline 1 person & 70 & $3.04 \pm 0.66$ & & $3.04 \pm 1.00$ & $(a<c)$ & $3.29 \pm 0.45$ & & $3.23 \pm 0.42$ & \\
\hline$\geq 2$ people & 68 & $2.92 \pm 0.68$ & & $3.14 \pm 0.77$ & & $3.33 \pm 0.57$ & & $3.28 \pm 0.49$ & \\
\hline
\end{tabular}

SD: standard deviation.

${ }^{\mathrm{a}, \mathrm{c}}$ Post hoc test was conducted from Scheffe test.

$* * \mathrm{p}<0.01$ by one-way ANOVA or t-test. 
2. Perception of work-family balance and work - family balance system, job satisfaction, and happiness level according to workplace form

The results of examining the differences in the perception of work-family balance and work-family balance system, job satisfaction, and happiness level according to the workplace form of the study subjects are reported in Table 2.

Table 2. Difference between Work-Family Balance and Work-Family Balance System Perception, Job Satisfaction, and Happiness Level according to Workplace Form

\begin{tabular}{|c|c|c|c|c|c|c|c|c|c|}
\hline \multirow[t]{2}{*}{ Variable } & \multirow[t]{2}{*}{$\mathrm{n}$} & \multicolumn{2}{|c|}{$\begin{array}{c}\text { Perception of } \\
\text { work-family } \\
\text { balance }\end{array}$} & \multicolumn{2}{|c|}{$\begin{array}{c}\text { Perception of } \\
\text { work-family } \\
\text { balance system }\end{array}$} & \multicolumn{2}{|c|}{ Job satisfaction } & \multicolumn{2}{|c|}{ Happiness level } \\
\hline & & Mean \pm SD & $\mathrm{t} / \mathrm{F}$ & Mean \pm SD & $\mathrm{t} / \mathrm{F}$ & Mean \pm SD & $\mathrm{t} / \mathrm{F}$ & Mean \pm SD & $\mathrm{t} / \mathrm{F}$ \\
\hline \multicolumn{10}{|l|}{ Workplace type } \\
\hline Dental clinic & 156 & $3.03 \pm 0.69$ & 0.380 & $2.90 \pm 0.86$ & $6.917 * *$ & $3.26 \pm 0.54$ & 0.897 & $3.18 \pm 0.44$ & $4.277^{*}$ \\
\hline Dental hospital & 24 & $3.06 \pm 0.69$ & & $3.03 \pm 0.71$ & $(\mathrm{a}<\mathrm{b}<\mathrm{c})$ & $3.37 \pm 0.49$ & & $3.36 \pm 0.54$ & $(a<c)$ \\
\hline General hospitals and university hospitals & 8 & $2.82 \pm 0.69$ & & $4.03 \pm 0.87$ & & $3.45 \pm 0.54$ & & $3.60 \pm 0.53$ & \\
\hline \multicolumn{10}{|l|}{ Total work experience (mo) } \\
\hline $1 \sim 60$ & 20 & $2.96 \pm 0.60$ & 0.492 & $2.68 \pm 0.64$ & $2.829^{*}$ & $3.40 \pm 0.47$ & 0.696 & $3.21 \pm 0.51$ & 1.355 \\
\hline $61 \sim 120$ & 67 & $2.96 \pm 0.64$ & & $2.99 \pm 0.86$ & & $3.22 \pm 0.52$ & & $3.15 \pm 0.40$ & \\
\hline $121 \sim 240$ & 81 & $3.08 \pm 0.75$ & & $3.11 \pm 0.90$ & & $3.29 \pm 0.53$ & & $3.25 \pm 0.51$ & \\
\hline$\geq 241$ & 20 & $3.06 \pm 0.69$ & & $2.59 \pm 0.87$ & & $3.33 \pm 0.63$ & & $3.38 \pm 0.48$ & \\
\hline \multicolumn{10}{|l|}{ Current job work experience (mo) } \\
\hline $1 \sim 36$ & 95 & $2.97 \pm 0.66$ & 0.901 & $2.80 \pm 0.79$ & $3.030^{*}$ & $3.25 \pm 0.54$ & 0.379 & $3.18 \pm 0.47$ & 1.358 \\
\hline $37 \sim 72$ & 40 & $3.02 \pm 0.63$ & & $3.17 \pm 0.96$ & & $3.27 \pm 0.53$ & & $3.19 \pm 0.38$ & \\
\hline $73 \sim 108$ & 17 & $3.26 \pm 0.75$ & & $2.90 \pm 0.56$ & & $3.37 \pm 0.49$ & & $3.34 \pm 0.48$ & \\
\hline$\geq 109$ & 36 & $3.06 \pm 0.78$ & & $3.22 \pm 1.01$ & & $3.33 \pm 0.55$ & & $3.33 \pm 0.55$ & \\
\hline \multicolumn{10}{|l|}{ Job rank } \\
\hline Staff & 89 & $2.98 \pm 0.64$ & $5.830 * *$ & $2.95 \pm 0.89$ & 0.445 & $3.15 \pm 0.53$ & $7.642^{* *}$ & $3.13 \pm 0.43$ & $4.665^{*}$ \\
\hline Team leader & 30 & $2.72 \pm 0.63$ & & $2.86 \pm 0.68$ & & $3.22 \pm 0.49$ & $(a<c)$ & $3.23 \pm 0.52$ & $(a<c)$ \\
\hline$\geq$ Manager & 69 & $3.21 \pm 0.73$ & & $2.78 \pm 0.93$ & & $3.47 \pm 0.50$ & & $3.35 \pm 0.48$ & \\
\hline \multicolumn{10}{|l|}{ Number of employees (persons) } \\
\hline$<10$ & 149 & $3.06 \pm 0.68$ & 2.869 & $2.92 \pm 0.87$ & 1.394 & $3.27 \pm 0.54$ & 0.563 & $3.20 \pm 0.47$ & 2.835 \\
\hline $10 \sim 49$ & 31 & $2.79 \pm 0.62$ & & $3.12 \pm 0.92$ & & $3.25 \pm 0.54$ & & $3.23 \pm 0.43$ & \\
\hline$\geq 50$ & 8 & $3.34 \pm 0.82$ & & $3.31 \pm 0.50$ & & $3.47 \pm 0.39$ & & $3.60 \pm 0.52$ & \\
\hline \multicolumn{10}{|l|}{ Average income (million won) } \\
\hline$<200$ & 17 & $2.81 \pm 0.53$ & $2.523^{*}$ & $2.75 \pm 0.71$ & 0.755 & $3.07 \pm 0.47$ & $5.061^{* *}$ & $2.91 \pm 0.39$ & $5.764^{* *}$ \\
\hline $200 \sim 249$ & 33 & $2.95 \pm 0.61$ & & $2.82 \pm 0.67$ & & $3.28 \pm 0.48$ & $(\mathrm{c}<\mathrm{d}, \mathrm{e})$ & $3.32 \pm 0.52$ & $(\mathrm{a}<\mathrm{d}, \mathrm{e})$ \\
\hline $250 \sim 299$ & 80 & $2.93 \pm 0.71$ & & $3.02 \pm 0.85$ & & $3.16 \pm 0.57$ & & $3.12 \pm 0.44$ & $(c<d)$ \\
\hline $300 \sim 349$ & 45 & $3.26 \pm 0.74$ & & $3.08 \pm 0.99$ & & $3.46 \pm 0.44$ & & $3.39 \pm 0.43$ & \\
\hline$\geq 350$ & 13 & $3.22 \pm 0.53$ & & $2.92 \pm 1.20$ & & $3.65 \pm 0.41$ & & $3.44 \pm 0.44$ & \\
\hline \multicolumn{10}{|l|}{ Whether vacation is used } \\
\hline Possible & 122 & $2.09 \pm 0.66$ & 1.918 & $2.99 \pm 0.87$ & 0.560 & $3.32 \pm 0.52$ & -1.420 & $3.24 \pm 0.44$ & 0.760 \\
\hline Impossible & 66 & $2.89 \pm 0.72$ & & $2.92 \pm 0.88$ & & $3.20 \pm 0.55$ & & $3.19 \pm 0.51$ & \\
\hline \multicolumn{10}{|l|}{ Childcare system } \\
\hline Yes & 80 & $3.05 \pm 0.65$ & 0.370 & $3.32 \pm 0.81$ & $5.10^{* *}$ & $3.40 \pm 0.43$ & $2.810^{* *}$ & $3.34 \pm 0.43$ & $2.990^{* *}$ \\
\hline No & 108 & $3.01 \pm 0.72$ & & $2.70 \pm 0.82$ & & $3.19 \pm 0.58$ & & $3.14 \pm 0.48$ & \\
\hline \multicolumn{10}{|l|}{ Parental leave period (mo) } \\
\hline$\leq 6$ & 16 & $3.02 \pm 0.61$ & 0.834 & $2.89 \pm 0.74$ & $3.189^{*}$ & $2.78 \pm 0.41$ & 0.825 & $3.25 \pm 0.37$ & 0.410 \\
\hline $7 \sim 12$ & 41 & $3.13 \pm 0.65$ & & $3.48 \pm 0.62$ & $(\mathrm{a}<\mathrm{b})$ & $3.44 \pm 0.44$ & & $3.34 \pm 0.43$ & \\
\hline$\geq 13$ & 23 & $2.91 \pm 0.67$ & & $3.34 \pm 1.04$ & & $3.41 \pm 0.42$ & & $3.49 \pm 0.47$ & \\
\hline
\end{tabular}

SD: standard deviation.

${ }^{\mathrm{a} \sim \mathrm{e}}$ Post hoc test was conducted from Scheffe test.

${ }^{*} \mathrm{p}<0.05,{ }^{* *} \mathrm{p}<0.01$ by one-way ANOVA or t-test. 


\section{1) Recognition of work-family balance according to workplace form}

There was a significant difference in the recognition level of work-family balance in job rank and average income $(p<0.05)$. In the job rank, the group above the manager was 3.21 points, indicating that the level of awareness of work-family balance was high; in average income, the recognition level was low at 2.81 points in the group under 200 million won.

\section{2) Recognition of work-family balance system according to workplace form}

There were significant differences in the perception of work-family balance system in workplace type, total work experience, current job work experience, childcare system status, and parental leave period $(\mathrm{p}<0.05)$. According to workplace type, both general and university hospitals were at 4.03 points, dental hospitals at 3.03 points, and dental clinics at 2.90 points. Regarding experience, the group who worked for 241 months or more had 2.59 points, and according to the length of time at the current hospital, the group that worked for $1 \sim 36$ months showed the lowest value of 2.80 points.

In addition, the group with childcare system (3.32 points) showed a higher awareness of the work-family balance system than the group without the childcare system, and the group with less than six months of parental leave (2.89 points) showed the lowest significance.

\section{3) Job satisfaction according to workplace form}

There were significant differences in job satisfaction in the job rank, average income, and childcare system $(\mathrm{p}<$ 0.05). According to the job rank, job satisfaction was highest in the above the manager group at 3.47 points, and the lowest in the staff group at 3.15 points. In terms of average income, job satisfaction was highest in the group with more than 350 million won (3.65 points), and the lowest in the group with less than 200 million won (3.07 points). The group with the childcare system (3.40 points) showed significantly higher job satisfaction than the group without it (3.19 points).

\section{4) Happiness level according to workplace form}

Workplace type, job rank, average income, and childcare system showed significant differences in happiness levels $(\mathrm{p}<0.05)$. In the workplace type, the group working at general and university hospitals had 3.60 points, while other hospitals and clinics had 3.36 and 3.18 points, respectively. According to the job rank, there were 3.35 points in the group of managers or higher, 3.23 points in the team leader level group, and 3.13 points in the staff group were sequentially indicated. Regarding average income, the happiness level was highest in the group with more than 350 million won (3.44 points), and the lowest in the group with less than 200 million won (2.91 points). The happiness level was significantly higher in the group with the childcare system (3.34 points) than in the group without it.

Table 3. Difference between Work-Family Balance and Work-Family Balance System Perception, Job Satisfaction, and Happiness Level according to Parenting Type

\begin{tabular}{|c|c|c|c|c|c|c|c|c|c|}
\hline \multirow[t]{2}{*}{ Variable } & \multirow[t]{2}{*}{$\mathrm{n}$} & \multicolumn{2}{|c|}{$\begin{array}{c}\text { Perception of } \\
\text { work-family balance }\end{array}$} & \multicolumn{2}{|c|}{$\begin{array}{c}\text { Perception of } \\
\text { work-family } \\
\text { balance system }\end{array}$} & \multicolumn{2}{|c|}{ Job satisfaction } & \multicolumn{2}{|c|}{ Happiness level } \\
\hline & & Mean \pm SD & $\mathrm{t} / \mathrm{F}$ & Mean \pm SD & $\mathrm{t} / \mathrm{F}$ & Mean \pm SD & $\mathrm{t} / \mathrm{F}$ & Mean \pm SD & $\mathrm{t} / \mathrm{F}$ \\
\hline \multicolumn{10}{|c|}{ Whether a child needs care } \\
\hline Yes & 90 & $2.93 \pm 0.67$ & -1.145 & $3.21 \pm 0.84$ & $2.215^{*}$ & $3.27 \pm 0.48$ & -1.207 & $3.22 \pm 0.44$ & -1.299 \\
\hline No & 48 & $3.07 \pm 0.68$ & & $2.87 \pm 0.95$ & & $3.38 \pm 0.54$ & & $3.33 \pm 0.47$ & \\
\hline \multicolumn{10}{|l|}{ Caring form } \\
\hline 1 person & 74 & $2.93 \pm 0.67$ & 0.384 & $3.18 \pm 0.86$ & 0.276 & $3.26 \pm 0.50$ & 1.570 & $3.21 \pm 0.45$ & 0.250 \\
\hline 2 people & 12 & $3.04 \pm 0.48$ & & $3.31 \pm 0.63$ & & $3.44 \pm 0.32$ & & $3.30 \pm 0.32$ & \\
\hline 3 people & 4 & $2.71 \pm 1.05$ & & $3.44 \pm 0.97$ & & $2.98 \pm 0.47$ & & $3.15 \pm 0.66$ & \\
\hline
\end{tabular}

SD: standard deviation.

$* p<0.05$ by one-way ANOVA or t-test. 
3. Perception of work-family balance and work - family balance system, job satisfaction, and happiness level according to parenting type

The results of examining the differences in the perception of work-family balance and work-family balance system, job satisfaction, and happiness level according to the parenting type of the study subjects are reported in Table 3.

Among the sub-domains of parenting type, there was a significant difference in the perception of work-family balance system in whether a child needs care $(\mathrm{p}<0.05)$. In groups with caring children, the perception of workfamily balance system was high at 3.21 points, and in the group without caring for children, the perception of workfamily balance system was low at 2.87 points. There was no difference according to parenting type in the perception of work-family balance, job satisfaction, and happiness level.
4. The correlation between work - family balance and work - family balance system perception, job satisfaction, and happiness level

The results of examining the correlation between workfamily balance and work-family balance system perception, job satisfaction, and happiness level are reported in Table 4.

The perception of work-family balance showed a significantly positive correlation between job satisfaction $(\mathrm{r}=$ 0.423, $\mathrm{p}<0.001)$ and happiness level $(\mathrm{r}=0.475, \mathrm{p}<0.01)$. The perception of the work-family balance system also showed a positive correlation between job satisfaction $(\mathrm{r}=0.246, \mathrm{p}<0.01)$ and happiness level $(\mathrm{r}=0.184, \mathrm{p}<$ $0.05)$. Job satisfaction and happiness levels $(\mathrm{r}=0.699, \mathrm{p}<$ $0.001)$ also showed a significantly positive correlation.

\section{The effect of the perception of work - family balance and work - family balance system, job satisfaction on happiness level}

The results of examining the effects of the perception of work-family balance and work--family balance system

Table 4. Correlation between Work-Family Balance and Work-Family Balance System Perception, Job Satisfaction, and Happiness Level

\begin{tabular}{|c|c|c|c|c|}
\hline Variable & $\begin{array}{c}\text { Perception of } \\
\text { work-family balance }\end{array}$ & $\begin{array}{c}\text { Perception of } \\
\text { work-family balance system }\end{array}$ & Job satisfaction & Happiness level \\
\hline Perception of work-family balance & 1 & & & \\
\hline Perception of work-family balance system & -0.037 & 1 & & \\
\hline Job satisfaction & $0.423 * * *$ & $0.246 * *$ & 1 & \\
\hline Happiness level & $0.475 * *$ & $0.184 *$ & $0.699 * * *$ & 1 \\
\hline
\end{tabular}

${ }^{*} \mathrm{p}<0.05, * * \mathrm{p}<0.01, * * * \mathrm{p}<0.001$ by Pearson correlation analysis.

Table 5. Effect of Work-Family Balance and Work-Family Balance System Awareness and Job Satisfaction on Happiness Level

\begin{tabular}{|c|c|c|c|c|}
\hline \multirow{2}{*}{ Variable } & \multicolumn{4}{|c|}{ Happiness level } \\
\hline & $\mathrm{B}$ & Standard error & $\beta$ & t-statistic \\
\hline (constant) & 16.963 & 3.009 & & $5.638 * *$ \\
\hline \multicolumn{5}{|l|}{ Whether a child needs care (ref. no) } \\
\hline Yes & 3.423 & 2.700 & 0.203 & 1.268 \\
\hline \multicolumn{5}{|l|}{ Caring form (ref. 3 people) } \\
\hline 1 person & -3.114 & 2.686 & -0.181 & -1.159 \\
\hline 2 people & -3.738 & 3.142 & -0.109 & -1.190 \\
\hline Perception of work family balance & 0.149 & 0.037 & 0.231 & $4.047 * *$ \\
\hline Perception of work family balance system & 0.094 & 0.134 & 0.039 & 0.706 \\
\hline Job satisfaction & 0.794 & 0.078 & 0.599 & $10.196^{* *}$ \\
\hline $\mathrm{F}(\mathrm{p})$ & \multicolumn{4}{|c|}{$34.660 *$} \\
\hline Adjusted $\mathrm{R}^{2}$ & \multicolumn{4}{|c|}{0.519} \\
\hline
\end{tabular}

${ }^{*} \mathrm{p}<0.05,{ }^{* *} \mathrm{p}<0.01$ by multiple regression analysis. 
and job satisfaction on happiness level is reported in Table 5.

The happiness level was found to be affected by the perception of work-family balance $(\beta=0.231, p<0.01)$ and job satisfaction $(\beta=0.599, \mathrm{p}<0.01)$. This is the result after adjusting for general characteristics (variables in Table 1) and workplace form (variables in Table 2), and it shows an explanatory power of $53.5 \%$. In other words, it can be explained that the higher the perception of workfamily balance and job satisfaction, the higher the happiness level.

\section{Discussion}

According to the 2018 Statistics Korea indicator ${ }^{3,4)}$, the ratio of double-income households was $46 \%$, but the ratio of housework was 50 to $60 \%$ for men and $99 \%$ for women. This shows that there is no balance between work and family, and that women are in charge of various roles in the family. For dental hygienists, a high proportion of them being women, it can be said that a harmonious workfamily balance will have a great impact on happiness level and quality of life. Therefore, in this study, the factors affecting happiness levels in work-family balance areas were investigated for married women dental hygienists in the Seoul/Gyeonggi area.

As a result of looking at the differences in work-family balance, system, and happiness level according to general characteristics, in the absence of children, the perception of work-family balance was high, but interest in the workfamily balance system was higher as the number of children increased. Jung ${ }^{17)}$ reported that the variable with the greatest relative influence on the work-family balance of married working women was the stress of raising children. Therefore, the more children there are, the higher the interest and necessity of the government system, so it is thought that organizational culture formation and official policy support for practical support are necessary.

In the lower domain of the workplace form, the higher the workplace type, job rank, and average income, and the more the childcare system existed, the better the recognition and happiness level were in the work-family balance. The results of the workplace type are shown to be similar to those that affect the work environment and job satisfaction according to hospital size in the study of Lee and $\mathrm{Kim}^{18)}$. In a study by Kim and Park ${ }^{19)}$, job satisfaction was higher as hospital size was large, training opportunities were given, and allowances were paid for long-term service and other vacations (menstrual leave, monthly leave, etc.). Based on these results, if the work environment is improved at the dental hospital and clinic level, the work-family balance and happiness level of married women dental hygienists can be developed in a better direction.

The higher the job rank, the higher the job responsibility and autonomy, and it is in the same vein as Jung's ${ }^{20)}$ study, who reports that autonomy and task importance have a significant effect on job satisfaction. However, according to $\mathrm{Ahn}^{21)}$, when women workers had high organizational commitment, they perceived that they could not properly perform their roles and responsibilities in the family, leading to an increase in work-family conflict, which differed from the results of this study. Thus, it is thought that if the social perception that women are obliged to bear the role of the family was improved, this would further improve personal responsibility and autonomy for work and will have a positive effect on the work-family balance and happiness level. As for average income, Lee's ${ }^{22)}$ study reports that the more satisfied the income, which leads to overall life satisfaction, thereby supporting the argument in the present study. This is thought to be a result of the fact that the level of affluence in life increases according to income.

The presence or absence of a childcare system is similar to that of Jang and Yi's ${ }^{23)}$ report that the ease of use of parental leave has the greatest impact on job satisfaction. Therefore, it is thought that a better work environment can be pursued if the ease of use of the system as well as the childcare system are improved. On the other hand, according to the announcement of the Korea Labor Institute $^{24)}$, although the length of parental leave for men in Korea is increasing every year, the proportion of men taking parental leave is at $13.4 \%$ (2017), which is very low. Consequently, it is thought that if men's free use of parental leave is used and social support is used to reduce the burden of childcare at home, an improved work-family balance will be exhibited. 
In the lower domain of the parenting type, it was found that the more children that needed care, the better the perception of the work-family balance system.

The above-mentioned results are consistent with the Kim's $^{25)}$ study, who report that employed women with several preschool children show a positive attitude toward direct service support policies including child care services. It can be said that this is in line with the studies of Park and $\mathrm{Un}^{26)}$ who report that the more women with preschool children recognize the contents of the institutional support system needed for work family balance, the more likely they would achieve work-family balance. This is thought to be because families that have the duty to support children in their care experience greater difficulties in work-family balance than families that do not. $\mathrm{Kim}^{25)}$ reported that employed mothers raising preschool children reported that the time support policy and service provision policy among the work-family balance system had a high positive effect, and that the negative effect of the vacation policy was also highly recognized. Therefore, it is necessary to revise the law that can be actively used by both men and women in pursuit of changes in maternity and parental leave systems.

As a result of analyzing the relationship between workfamily balance and perception of the work-family balance system, job satisfaction, and happiness level, when each of these factors was high, a positive correlation with effectiveness was also confirmed. The effects of the perception of work-family balance and work-family balance system, and job satisfaction on happiness level were found to affect happiness level in the perception of work-family balance and job satisfaction. Previous studies have reported that although expectations and demands are increasing for men participation in family life, the overall atmosphere, perception, and values of the society have not changed $^{14,27)}$. Since the 2000 s, the government has made several policy efforts, such as support for the work-family balance in order to increase fertility rates but has reported that double-income families do not favor $\mathrm{it}^{28)}$. In particular, the lower the household income, the lower the recognition of the work-family balance support policy for companies with fewer than 50 employees and temporary positions $^{29)}$. In the case of dental hygienists, the ratio of those working in dental hospitals (clinics) is higher than those in general hospitals, and even though there is a government support system, it is thought that the results are not highly effective and recognized.

In addition, it has been mentioned that the job satisfaction of a dual-income couple affects the conflict between the rectal and the family or the complementary relationship, and if the balance between work and family is not achieved, it will affect job satisfaction in the workplace $^{5,12,13,21)}$. In addition, according to a study by $\mathrm{Yu}^{30)}$, it was reported that job satisfaction at a professional rather than an individual level had a very high effect on happiness. In addition, economic factors have a great influence as one of the factors that improve the quality of life ${ }^{27)}$. Therefore, for women dental hygienists to maintain a high level of happiness by reconciling work and family, it is necessary to improve their perception not only individually but also socially. In addition, it can be assumed that the work environment affects both professionalism and job satisfaction. Accordingly, in the workplace, the workplace childcare support system, parental leave system, flexible working system, and incentive system for dental hygienists should be actively implemented by providing a family friendly workplace culture. It is thought that a change in the perception is necessary which entails that the work-family balance system is one that all workers can use. This system improvement is thought to be helpful for the career interruption of women dental hygienists and proper supply of manpower for dental care.

The limitations of this study included the study subjects being limited to Seoul and Gyeonggi regions, and difficulties in recruiting study subjects due to COVID-19. As a result, the generalization of the study results is limited. Therefore, future follow-up studies should expand the study area to the entire country. In addition, since only self-reported questionnaires are used, there is the uncertainty that specific matters and subjective characteristics, other than that of the questionnaire items, cannot be known. Therefore, it is recommended that various survey methods, such as interview surveys and questionnaire surveys, are needed for more accurate evaluations in follow-up studies. 


\section{Notes}

\section{Conflict of interest}

No potential conflict of interest relevant to this article was reported.

\section{Ethical approval}

This study was approved by the Institutional Review Board of Eulji University (IRB-2020-1).

\section{Author contributions}

Conceptualization: Hee-Jung Lim. Data acquisition: all the authors. Formal analysis: all the authors. Funding: Hee-Jung Lim and Ae-Jung Im. Supervision: Hee-Jung Lim and Ae-Jung Im. Writing-original draft: all the authors. Writing-review \& editing: Hee-Jung Lim and Ae-Jung Im. All authors approved the final manuscript.

\section{ORCID}

Ae-Jung Im, https://orcid.org/0000-0003-2752-7112

Yun-woo Kim, https://orcid.org/0000-0001-5030-3569

Su-jung Kim, https://orcid.org/0000-0001-5554-8864

Seung-yeon Kim, https://orcid.org/0000-0003-4741-4107

Eo-jin Kim, https://orcid.org/0000-0002-4864-1697

So-dam Moon, https://orcid.org/0000-0003-3649-3508

Su-min Shin, https://orcid.org/0000-0002-0299-3945

Hae-in Jeong, https://orcid.org/0000-0003-4270-0331

Hee-Ae Jeong, https://orcid.org/0000-0001-8387-9839

Hee-Jung Lim, https://orcid.org/0000-0002-4738-3032

\section{References}

1. Song EJ, Yhang WJ, Kim BK: The effect of LCC cabin crews' work-life balance on job satisfaction and turnover intention. NATR 15: 65-79, 2019.

https://doi.org/10.35173/NATR.15.4.4

2. Han JY: A study on labour law's legislative issues for realizing gender-mainstreating of work-family balance system. Ewha J Gend Law 1: 455-474, 2010.

3. Statistics Korea: 2018 Work and family balance indicators. Retrieved 2021 Mar 21, from https://www.kostat.go.kr/ portal/korea/kor_nw/1/1/index.board?bmode $=$ read $\&$ aSeq $=3$ 72028(2018, December 14).
4. Statistics Korea: 2018 Regional employment survey for the second half: employment status of dual-income and single-person households. Retrieved 2021 Mar 21, from https://www.kostat.go.kr/portal/korea/kor_nw/1/1/index.boa rd?bmode=read\&aSeq=375478(2019, June 25).

5. Kim KM, Kye SJ: A Study on Work-Family Balance and the Happiness level of Dual Career Families. J Korean Home Manag Assoc 36: 103-119, 2018. https://doi.org/10.7466/JKHMA.2018.36.4.103

6. Statistics Korea: 2019 Women's lives through statistics. Retrieved 2021 May 10, from https://www.kostat.go.kr/ portal/korea/kor_nw/1/1/index.board?bmode $=$ read $\&$ aSeq $=3$ 75629(2019, July 1).

7. Lee ES, Kang HS, Kim KW, et al.: Introduction to dental hygiene. Komoonsa, Seoul, pp. 5, 2017.

8. Statistics Korea: 2017 The regional employment survey. Retrieved 2021 Jun 5, from http://kostat.go.kr/portal/korea/ kor_nw/1/3/3/index.board?bmode $=$ read $\& b S e q=\& a S e q=368$ 486\&pageNo $=3 \&$ rowNum $=10 \&$ navCount $=10 \&$ currPg $=\&$ se $\operatorname{archInfo}=\&$ sTarget $=$ title \&sTxt=(2018, June 21$)$.

9. Moon JH: Research on the support of work-life balanced work culture in Busan. Busan Women and Family Development Institute, Busan, pp.6-40, 2018.

10. Noh SM, Lim HJ, Kim MH, Im AJ, Lim DS: Factors affecting the turnover intention of dental hygienists: emotional labor, job satisfaction, and social support. J Dent Hyg Sci 18: 271-279, 2018. https://doi.org/10.17135/jdhs.2018.18.5.271

11. Lee SW, Nam JS: A study on the relationships between work-family reconciliation and turnover intention of married Female Police Officer. Korean Police Stud Rev 19: 183-212, 2020.

https://doi.org/10.38084/2020.19.1.8

12. Lee JS, Choi WS: A study on the effects of work-family support system on job satisfaction: focused on social workers in Daegu. JLGS 13: 163-187, 2018. https://doi.org/10.16973/jgs.2018.13.1.007

13. Sim SH, Seo YJ: Determinants of occupational commitment of dental hygienists. Korea J Hosp Manag 13: 84-102, 2008.

14. Lee KJ, Bae HS: The factors affecting the intention of career discontinuity of a married women dental hygienist. J Dent Hyg Sci 15: 786-793, 2015.

https://doi.org/10.17135/jdhs.2015.15.6.786 
15. Jeong SD: A study on the correlation between job characteristics and job satisfaction in gastrointetinal endoscopy unit nurses. Unpublished master's thesis, Catholic University of Korea, Bucheon, 2018.

16. Kim DK: Work-life balance imbalance and vacation use gap. Gyeonggi Res Inst 389: 1-25, 2019.

17. Jung SA: The effects of work-family nalance with individual, family and job variables of married female worker. Unpublished master's thesis, Pusan National University, Busan, 2012.

18. Lee MH, Kim JK: A comparative study on nursing practice environment, professionalism, and job satisfaction according to hospital size. J Korean Acad Nurs Adm 19: 470-479, 2013. https://doi.org/10.11111/jkana.2013.19.4.470

19. Kim YS, Park HS: A study on work environment and job satisfaction of dental hygienists in Daegu and Gyeongsangbuk-do. J Dent Hyg Sci 12: 600-606, 2012.

20. Jung SH: The effects of medical secretaries's job characteristics on job attitudes. J Secr Stud 26: 133-154, 2017. https://doi.org/10.35605/jss.2017.04.26.1.133

21. Ahn EJ: A study on antecedents of work-family conflict: family-friendly organization, work characteristics, role involvement or demographic factors. DRSR 11: 75-120, 2013. https://doi.org/10.16958/drsr.2013.11.2.75

22. Lee HS: On the relationship of income and life satisfaction: a comparison of absolute and relative theory. J Labour Econ 24: 231-251, 2001.

23. Jang KS, Yi YJ: Influence of awareness and perceived ease in using parental leave on job satisfaction of nurses in a public hospital. J Korean Acad Nurs Adm 24: 211-220, 2018. https://doi.org/10.11111/jkana.2018.24.3.211

24. Cho KJ: Labor review- parental leave status of Korean men. Korea Labor Institute, Sejong, pp.96-98, 2018.

25. Kim EJ: Do working mothers with preschool children recognize and intend to use work-family reconciliation policy? An analysis of the difference between time support policy and service provision policy. Korean Soc Public Adm 24: 617-642, 2013.

26. Park HJ, Un SK: A study on the factors influencing the reentry of career interruptive women into the labor market: with a focus on the compatibility of job and family for women with preschool aged children. KJFW 17: 5-29, 2012.

27. Park YS, Kim UC: Factors influencing quality of life for individuals and Korean society: Indigenous psychological analysis across different generations. Korean Psychol J Cult Soc Issues 12: 161-195, 2006.

28. Kim YM: Korea's work-family balance reality and alternatives. Mon Welf Trend 175: 13-18, 2013.

29. Ministry of Gender Equality and Family: Results of public feeling surveys on work-life balance policies. Retrieved 2021 Jun 5, from http://www.mogef.go.kr/nw/rpd/nw_rpd_s001d. do?mid=news405 (2016, November 21).

30. Yu YJ: Effect of professional identity on the happiness of social workers: focused on job satisfaction mediated effect. KSW 15: 357-366, 2020. https://doi.org/10.21097/ksw.2020.02.15.1.357 